\title{
The Relevance of Franz L. Neumann's Critical Theory in 2017: Anxiety and Politics in the New Age of Authoritarian Capitalism
}

\section{Christian Fuchs}

\author{
University of Westminster, London, UK, christian.fuchs@uti.at, @fuchschristian
}

\begin{abstract}
This articles discusses and contextualises tripleC's republication of Franz L. Neumann's essay Anxiety and Politics. It provides some background information on Neumann's life and works. The essay ascertains that in the age of new nationalisms, rising right-wing authoritarianism and authoritarian capitalism, Franz L Neumann's works can help us to critically understand contemporary society.
\end{abstract}

Keywords: Franz L. Neumann, critical theory, authoritarian capitalism, right-wing authoritarianism, political theory, political economy, political psychology, psychoanalysis, ideology critique

\section{Who Was Franz Leopold Neumann? ${ }^{1}$}

Franz Leopold Neumann (1900-1954) was a German, Jewish political theorist associated with the Frankfurt School. He was born in Kattowitz/Katowice. He was part of the left wing of the German Social Democratic Party SPD. Neumann was influential in the organisation of the Socialist Students in Frankfurt and participated in the 1918 November revolution. He received training in legal studies in Breslau, Frankfurt, Leipzig and Rostock. He obtained a doctoral degree in legal studies at the University of Frankfurt with the dissertation A Legal-Philosophical Introduction to A Treatise on the Relationship between the State and Punishment (Neumann 1923). After that, he worked as assistant of Hugo Sinzheimer, who was a professor of legal studies at Frankfurt University. Neumann was a practicing advocate who specialised in labour law. In 1927, Neumann together with Ernst Fraenkel started a lawyer's office in Berlin. They both worked for trade unions: Neumann specialised on legal cases for the construction workers' union, Fraenkel's focused on support for the metal workers' union. Neumann became the German Social Democratic Party's main legal advisor at a time when the Nazis and Hitler gained strength in Germany. When Hitler came to power in 1933, the legal office had to be closed. Neumann had to flee from Germany and went to London, where he started studying political science and sociology at the London School of Economics (LSE).

At the LSE, Neumann held a PhD scholarship and worked under the guidance of Harold Laski and Karl Mannheim on a second dissertation. As a result, he in 1936 obtained his second doctoral degree with the work The Governance of the Rule of Law (Neumann 1936b). He moved to New York in 1936, where he became a member of the Institute of Social Research (also known as the "Frankfurt School") that

\footnotetext{
${ }^{1}$ For a detailed discussion of Franz L. Neumann's biographical and intellectual history, see Söllner (2011), Söllner (1996, 1982), Scheuerman (1997), as well as the interviews and conversations published in Erd (1985).
} 
was then in exile in the USA and associated with Columbia University. In 1942, he started working for the Office of Strategic Service (OSS), where he together with Herbert Marcuse and Otto Kirchheimer analysed Nazi Germany. After the War, he contributed to writing indictments in the Nuremberg trials. Neumann stayed in the USA. In 1948, he was appointed professor of political science at Columbia University. He died in 1954 in a car accident.

Alfons Söllner (2001) distinguishes three periods in Neumann's works and life:

1) the Weimar period up until 1933 when he had to flee from Nazi Germany;

2) the time of the Nazi regime and the Second World War (1933-1945);

3) the post-war time until Neumann's death in 1954.

It is "Neumann's unusual tripartite course - his path from legal practice via confrontation with Nazism to political science - which is of general significance" (Söllner 2001, 123). In the Weimar phase, Neumann focused on legal practice and theory. The time of the Nazi regime and the Second World War was according to Söllner (2001, 125) Neumann's most materialistic phase. Neumann certainly was always a materialist thinker, but this phase, in which he wrote and published Behemoth, certainly was one, where he heavily engaged with and made use of Marxist theory. In the post-war years, Neumann contributed to the establishment of political science as a field in general and West German political science, and he also worked on foundations and various elements of a theory of modern dictatorship (Söllner 2001, 131). In the third phase, Neumann increasingly combined political theory, the materialist theory of alienation, and political psychology. Anxiety and Politics, the essay that tripleC republishes in 2017, was written during Neumann's third phase.

\section{Behemoth: Franz Neumann's Analysis of the Structure and Practice of the Economy, the State and Ideology in Nazi Germany}

Neumann's (2009/1944) main book is Behemoth: The Structure and Practice of National Socialism, 1933 - 1944. It was first published in 1942. Neumann brought out an updated and expanded version in 1944. Herbert Marcuse $(1941,410)$ writes that Neumann's book shows that the "roots of Fascism are traceable to the antagonisms between growing industrial monopolization and the democratic system".

One of the book's basic hypotheses is that Nazism is not a state, but a form of political violence that Neumann based on Thomas Hobbes terms the Behemoth. Neumann argues that Nazism repealed the rule of law and substituted it by irrationality. "Behemoth, which depicted England during the Long Parliament, was intended as the representation of a non-state, a situation characterized by complete lawlessness" (Neumann 2009/1944, 459). For Neumann, Nazism was a lawless and irrational monster that he termed the Behemoth.

Peter Hayes argues in the book's introduction:

"Like the Behemoth in Jewish mythology and the writings of Thomas Hobbes, Hitler's regime was a chaotic, lawless, and amorphous monster. Its policies expressed the sometimes overlapping and sometimes contending drives of the four symbiotic but separate power centers (the Nazi party, the German state bureaucracy, the armed forces, and big business) that composed it. Both the enormous might and the inherent vulnerability of Nazi Germany stemmed, according to Neumann, from its very nature as a conspiracy among these four self-interested groups, each of which sought to expand German power and territory without ceding authority or status to any of the other parties" (Neumann 
2009/1944, vii).

In European Trade Unionism and Politics, Neumann $(1936 \mathrm{~b}, 85)$ defines fascism as "dictatorship of the fascist (National Socialist) party, the bureaucracy, the army and big business - dictatorship over the whole of the people, for the complete organization of the nation for imperialist war". Neumann here identifies some core characteristics of fascism:

1) Fascism is based on authoritarian leadership;

2) Fascism is nationalist; it propagates that "employers and workers work together in perfect harmony" (39) although class society and the division of labour continue to exist

3) Fascism is a dictatorial form of capitalism;

4) Fascism uses militaristic means (such as war, terrorism, and imperialism).

A feature that is missing is that 5 ) fascism uses the friend-enemy scheme for creating imagined enemies and scapegoats in order to distract from social problem's foundations in class inequality and power asymmetries. In Behemoth, Neumann worked out the critical theory of fascism in more detail.

Neumann argues that Nazism consists of four groups all functioning based on the leadership principle: monopoly capital, the party, the military, and bureaucracy.

"Under National Socialism, however, the whole of the society is organized in four solid, centralized groups, each operating under the leadership principle, each with a legislative, administrative, and judicial power of its own. Neither universal law nor a rationally operating bureaucracy is necessary for integration. Compromises among the four authoritarian bodies need not be expressed in a legal document nor must they be institutionalized (like the 'gentlemen's agreements' between monopolistic industries). It is quite sufficient that the leadership of the four wings agree informally on a certain policy. The four totalitarian bodies will then enforce it with the machinery at their disposal. There is no need for a state standing above all groups; the state may even be a hindrance to the compromises and to domination over the ruled classes. The decisions of the Leader are merely the result of the compromises among the four leaderships" (Neumann 2009/1944, 468-469).

Friedrich Pollock (1941a, 1941b) argues that Nazism was a totalitarian state capitalism, where "the profit motive is superseded by the power motive" $(1941 \mathrm{~b}, 207)$ and that it was based on the "masochistic submission to all kinds of commands, to suffering, sacrifice, or death" (1941a, 449). Totalitarian state capitalism would have been a new order that succeeded private capitalism (450). "The recognition of an economic sphere into which the state shall not and cannot intrude, so essential for the era of private capitalism, is being radically repudiated. In consequence, execution of the program is enforced by state power and nothing essential is left to the functioning of laws of the market or other economic 'laws.' The primacy of politics over economics, so much disputed under democracy, is clearly established" (Pollock 1941a, 453). Max Horkheimer $(1940,1941)$ followed Pollock's state capitalism approach, although he more foregrounded aspects of ideology and instrumental reason. "State capitalism is the authoritarian state of the present. [...] The self-movement of the concept of the commodity leads to the concept of state capitalism" (Horkheimer 1940, 96, 108).

Neumann disagreed with Friedrich Pollock's assessment that Nazism was a new order of state capitalism that had replaced monopoly capitalism. In state capitalism, 
according to Pollock there would be a primacy of politics over the economy. Horkheimer largely followed Pollock's approach. Neumann did not share the assumption that state power strongly limited capital's power in Germany. He rejected the term state capitalism and characterised Nazism as totalitarian monopoly capitalism. Neumann argued that Nazism combined monopoly capitalism and a command economy and did thereby not bring about a new order and did not replace monopoly capitalism. "The German economy of today has two broad and striking characteristics. It is a monopolistic economy - and a command economy. It is a private capitalistic economy, regimented by the totalitarian state. We suggest as a name best to describe it, 'Totalitarian Monopoly Capitalism"' (Neumann 2009/1944, 261). There were both capitalist and state interests (the latter involving the Nazi party, bureaucracy and the military) in Nazism that converged in the war economy: The Nazi regime wanted to arm Germany for an imperialist World War in order to accumulate power. Germany's large industry welcomed such efforts because armament meant its expansion and possibilities for capital accumulation. Whereas Pollock more stresses the discontinuities between capitalism and fascism, Neumann tends to foreground the continuities.

Underlying Neumann's critique of the term totalitarian state capitalism is the assumption that "a state is characterized by the rule of law" (Neumann 2009/1944, 467) and that Nazi Germany was therefore not a state. Certainly not everyone will agree to such a concept of the state. Neumann (1936b) argues that the state in Nazi Germany was a racist state (559) and a leadership state (562), in which the "law is the will of the Leader in the form of law" (562). The rule of law did not exist (571). Instead Hitler and his cabinet passed laws per decree. The independence of the judiciary did not exist, the judge was "the absolute servant of the law, i.e., of the will of the Leader. [...] The judge was to serve the Leader" (573-574). There was no separation of legislative, executive and judiciary power. Hitler had "supreme legislative and executive power" and also took on "judicial functions" (577). Neumann therefore concludes that the Nazi state was "in no way a Rechtsstaat" (570). He here differentiates between the state and a state under the rule of law and makes clear that Nazi Germany was a state without rule of law. This does not imply that it is not a state. It was not an Unstaat (non-state), but rather an Unrechtsstaat (state of injustice, unjust/tyrannical state).

Herbert Marcuse and Franz Neumann were close friends. Marcuse's first wife died in 1951 and Franz Neumann in 1954. Herbert Marcuse married Neumann's widow Inge in 1956. Neumann and Marcuse's works also resonated in many respects. Marcuse shared Neumann's view that Nazi fascism was totalitarian monopoly capitalism: "For in the totalitarian theory of the state the foundation of this society, i.e. the economic order based on private property in the means of production, are not attacked. Instead, they are only modified to the degree demanded by the monopolistic stage of this very economic order" (Marcuse 1934, 21). In the manuscript State and Individual Under National Socialism, Marcuse $(1942,69)$ refers to the first edition of Behemoth and argues that Neumann has shown that Nazi fascism has not abolished monopoly capitalism. Marcuse writes based on Neumann that big capital, the Nazi party and the army divided power in Nazi Germany.

Some authors stress that there were major differences between the approaches of Neumann, Kirchheimer, Gurland, and Marcuse on the one side and Pollock, Horkheimer, and Adorno on the other side (Held 1990, 52-53). So for example Martin Jay in his book The Dialectical Imagination: A History of the Frankfurt School and the Institute of Social Research argues: "Franz Neumann's general indifference towards psychology was one of the factors preventing his being fully accepted by the Institut's 
inner circle" (Jay 1996, 87). "Behemoth did contain short section on the psychology of charisma, but it ignored the Institut's earlier work on the authoritarian personality entirely. There was scarcely anything in Behemoth's more than six hundred pages (including an appendix added in 1944) to suggest that Neumann accepted Fromm's notion of the sado-masochistic character type" (Jay 1996, 162). It is certainly true that Behemoth does not contain any discussion of Freud, which however does not imply that the book ignores psychology. Jay's criticism cannot be upheld. Neumann $(2009 / 1944,402)$ for example writes in Behemoth that in "terms of modern analytical social psychology, one could say that National Socialism is out to create a uniformly sado-masochistic character, a type of man determined by his isolation and insignificance, who is driven by this very fact into a collective body where he shares in the power and glory of the medium of which he has become a part".

It is an idiosyncratic critique to say that Neumann represents an orthodox Marxism (Jay 1996, 165) and "minimized the independent importance of anti-Semitism and racism in general" (162). Quite to the contrary, Neumann (1943, 27-28) stressed that anti-Semitism was "the most constant single ideology of the Nazi Party. [...] We may, indeed, say that anti-Semitism is the sole ideology that can possibly cement the Nazi Party [...] Anti-Semitism is thus the spearhead of terror".

Rolf Wiggershaus in contrast in his book The Frankfurt School: Its History, Theories, and Political Significance argues that not only Neumann, but also Adorno voiced criticism of Pollock's approach on Nazism (Wiggershaus 1995, 282), whereas Horkheimer defended Pollock. Adorno thought that Pollock politically assessed state capitalism too positively. Wiggershaus stresses the parallels between Neumann and Pollock and that their differences were rather at the level of words than of a fundamental theoretical nature: "Neumann's analysis of the relations between the party, the state, the armed forces and the economy made it clear that his differences of opinion with Pollock were basically quibbles about words. The development which Neumann described clearly pointed in the same direction as that for which Pollock had chosen the unhappy term 'state capitalism'” (Wiggershaus 1995, 288-289). The basic difference between Neumann on the one side and Pollock and Horkheimer on the other was that "Neumann insisted on the basically capitalist character of the Nazi system, and therefore thought the notion had been disproved that an unexpected new social formation and a fundamental anthropological transformation had forced their way ahead of socialism, overtaking all the hopes which had been raised in the previous decades" (289-290). Horkheimer thought that Behemoth left out the culturalanthropological dimension of analysis.

A prejudice about the Frankfurt School is that it reduced Marxism to culture and ideology and ignored Marx's political economy. The way Marx understood political economy is evident in Capital Volume 1 (see Fuchs 2016). Marx starts the analysis of capitalism with the analysis of the commodity form. This analysis involves aspects of value, labour, and fetishism. Value and labour form the level of the productive forces, whereas fetishism deals with the way that subjectivity and intersubjectivity in a commodity-producing society appear as things and objects as well as with the subjective experience of humans in a society shaped by the commodity form. So a true critical political economy-analysis focuses on economy, politics and ideology/culture. The Frankfurt School under Horkheimer's leadership advanced interdisciplinary studies that brought together many different perspectives. The works of Neumann, Kirchheimer, Gurland and Pollock show that the analysis of the capitalist economy was an important element of the Frankfurt School at the time of Horkheimer and Adorno. "The work of Pollock, Neumann and Gurland is often ignored by critics of the Frank- 
furt school. If it were properly addressed, the charge that the school neglected political economy would lose a great deal of its force" (Held 1990, 360).

Behemoth is a good example: It brings together economic, political and ideological analysis. Neumann starts the analysis with an introduction that focuses on Nazism's pre-history and context in the Weimar Republic. The book's first part ("The Political Pattern of National Socialism)" starts with remarks on Nazi ideology. Neumann $(2009 / 1944,38)$ argues that it is opposed to "all traditional doctrines and values", including liberalism, democracy and socialism. The second part focuses on the "Totalitarian Monopoly Economy". The third part is about "The New Society" and focuses on Nazism's class structure.

Neumann shows how politics, economy and ideology interacted in the Nazi system. In his analysis of Nazism's political system, he analyses how the leadership ideology, anti-Semitism and racist imperialism shaped politics under Hitler. "The justification of this [leadership] principle is charismatic: it rests on the assertion that the Leader is endowed with qualities lacking in ordinary mortals. Superhuman qualities emanate from him and pervade the state, party, and people" (Neumann 2009/1944, 99). Nazism is ideologically an "Anti-Semitic movement" that advocates "the complete destruction of the Jews" (111). The compulsory acquisition of Jewish property and the Jews' deprivation of rights strengthened big business (117) and satisfied "the anti-capitalistic longings of the German people" (121). So terroristic state power had both economic and ideological dimensions and was driven by the political-ideological motive to annihilate the Jews. Nazism ideologically justified the Second World War as a war against "plutocratic-capitalistic Jewish democracies" (187). Imperialist warfare was justified as a "proletarian" warfare of the "Aryan race" against an imagined unity of capitalism, democracy, liberalism, socialism, and Marxism. Neumann speaks of the ideology of racial proletarianism (188). Nazism's military strategy both had an ideological aspect (the destruction of perceived enemies) and an economic dimension (the creation of Lebensraum for the biological expansion of "Aryans" and the biological and economic expansion of Germany).

In part two, Neumann shows that Nazism's economy featured compulsory cartellisation, the organisation of the entire economy based on the leader, the growth of monopolies via "Aryanisation", Germanisation, technological progress in the heavy industries, and the elimination of small and medium businesses, state intervention into the economy via the control of prices, investments, trade and the labour market (the abolishment of workers' rights, the ban of trade unions and collective bargaining, compulsory labour). Neumann shows how ideology (leadership ideology, antiSemitism), militarism, the command economy and totalitarian politics were fused into a total system of control, annihilation, accumulation, expansion, and imperialist warfare.

For the economic part of the book, Neumann could draw on knowledge by Arkadij R. L. Gurland, who like Neumann had fled from Nazi-Germany to the USA and was a researcher at the exiled Institute of Social Research. Gurland (1941) published for example an analysis of Nazi Germany's technology and economy in the Institute's journal. In respect to section 2.III (The Monopolistic Economy), Neumann mentions in an endnote that he "discussed all the problems of this section" with Gurland (Neumann 2009/1944, 503, footnote 38). Neumann writes in the preface that Gurland "placed his comprehensive knowledge of German industry at my disposal" (Neumann 2009/1944, xx).

In section three, Neumann shows how Nazism's ideology and class system interacted. Ideologically, Nazi fascism "claims to have [...] created a society differentiated 
not by classes but according to occupation and training" (367). But in reality it under the ideological guise of racism and nationalism would have "deepened and solidified" class antagonisms (367). Nazism organised society in "a monistic, total, authoritarian" (400) manner that was ideologically presented as an "abstract 'people's community,' which hides the complete depersonalization of human relations and the isolation of man from man" (402). "The essence of National Socialist social policy consists in the acceptance and strengthening of the prevailing class character of German society, in the attempted consolidation of its ruling class, in the atomization of the subordinate strata through the destruction of every autonomous group mediating between them and the state, in the creation of a system of autocratic bureaucracies interfering in all human relations" (367). Nazism's totalitarian monopoly capitalism deepened capitalist class structure via a terroristic state that driven by anti-Semitic and racist ideology abolished the rule of law and exercised upmost violence.

\section{Anxiety and Politics and its Relevance in 2017}

Anxiety and Politics was first published in German as Angst und Politik in 1954. The English translation was published in the volume The Democratic and the Authoritarian State: Essays in Political and Legal Theory that Herbert Marcuse edited in 1957 after Neumann's death in a car accident in Switzerland. Anxiety and Politics has again become of key importance in the times we live in today, which forms the background for tripleC's republication of the essay.

In the article Approaches to the Study of Political Power, Neumann argues: "The devices and forms for the translation of economic power into political power thus vary considerably and yet patterns are discernible which ought to be more sharply defined on a comparative basis" (Neumann 1957, 14). Neumann here stresses that political economy is contextual and that the interaction of economic, political and ideological power depends on specific societal conditions. We today live in a conjuncture of economic and political crisis that opens us power to changes and is shaped by two main tendencies.

On the one hand there is a tendency of the de-globalisation of the economy and the rise of more nationally contained economies, in which state intervention favours national capitalist interests and monopolies. To a certain degree one can here speak of some elements of state capitalism. Examples are the British decision to leave the European Union, which takes Britain out of a major regional free trade association, and the election of Donald Trump as US president. Trump has voiced criticisms of free trade agreements such as NAFTA (North American Free Trade Agreement) and TPP (Trans-Pacific Partnership) because he thinks that Mexico and China are threatening US jobs. Trump's critique is not a critique of capitalism, but a nationalist critique that pits nations against each other and disregards the underlying conflict between global capital and labour (Fuchs 2017). He seems to aim at a more nationally contained US capitalism that features low capital taxation and a high exploitation of labour as well as state power that is partly directly controlled by the billionaires and thereby intervenes in favour of US capital interests (Fuchs 2017). He also argues in favour of a "Keynesian neoliberalism" that makes public investments into infrastructure projects that are controlled, carried out and whose results are owned by private for-profit corporations.

On the second hand we have in different parts of the world experienced an increase of nationalism and authoritarian power. Since the mid-1970s, neoliberal capitalism has become the dominant capitalist model and form of governance. It mas- 
sively strengthened capitalist interests and weakened working class interests by commodification, privatisation, market liberalisation, deregulation, financialisation, international competition states, and a regime of low/no capital taxation. As a result, inequalities have been rising throughout the world. The world economic crisis that started in 2008 was a turning point: States turned towards state-capitalist measures in order to bail out banks and auto companies. At the same time, hyper-neoliberal austerity measures were launched. Right-wing demagogues used political fetishism for blaming migrants, refugees, welfare recipients, and other nations for the crises. Although there were some forms of progressive rebellion (such as the Occupy movements and the rise of Syriza, Podemos, Bernie Sanders, and Jeremy Corbyn), nationalism and authoritarianism have tended to be far-stronger tendencies. They distract attention from class questions by presenting social questions in terms of nationalism and xenophobia.

For Neumann $(1957,2017)$, democracy is the unity of personal/civil, political and social rights. Neumann experienced the rise of Nazism in Germany and how democratic rights were thereby undermined. Writing in the USA in the early 1950s, the time of McCarthyism, he feared the rise of a dictatorship and therefore warned that dictatorships emerge when civil, political and social rights are undermined and suspended. The "transformation from democracy into dictatorship seems to arise when the political system discards its liberal element and attempts to impose a creed upon its members, ostracizing those who do not accept it" (Neumann 1957, 194).

"The real difference between democracy and dictatorship consists first in the boundlessness of political power of dictatorship in contrast with the voluntary restrictions which democracy imposes upon itself - that ant nothing else is the meaning of the rule of the rights of man; secondly, in the responsibility of the holders of political power to the people, for democracy is not direct popular rule, but responsible parliamentary or governmental rule in contrast with the theory and practice of the irresponsibility of a political power that rests upon the leadership principle. Thirdly, in a democracy political power is to be rationally employed, not only negatively to keep down private social power, but positively to shape a decent existence. This is often ignored" (Neumann 1957, 269).

Neumann distinguishes between simple dictatorship, caesaristic dictatorship, and totalitarian dictatorship (Neumann 1957, 233-256). Although it is untrue that Neumann ignored aspects of subjectivity in Behemoth, it can certainly be said that the book is more a combination of institutional analysis and ideology critique. The interesting aspect of his late work, including the essay Anxiety and Politics, is that it combines the institutional analysis of political economy with ideology critique and the analysis of subjectivity and socio-psychology. Neumann asked himself how it could be that authoritarianism existed as ideological and political movement and how it could be that citizens followed it. One can say that in his late work, Neumann tried to combine Marx and Freud and took up Freudo-Marxian elements. This becomes evident by the fact that Neumann in Anxiety and Politics discusses, quotes and engages with Freud, whereas in Behemoth any such reference is missing. "Compared with the Behemoth, the emphasis on the economic determinants has receded, but only in order to place these determinants in a more concrete framework. [...] One of the problems with which he was most concerned was the support for dictatorship among the underprivileged masses" (Herbert Marcuse, in: Neumann 1957, ix). Anxiety and Politics tries to unite the objective and the subjective analysis of politics and capitalism. 
One could say it combines the analysis of Behemoth with Adorno and Fromm. It takes into account aspects of capitalist development, the state, ideology, and sociopsychology (see also Erd 1985, 200-206, 218-220).

Based on Freud, Neumann argues that fear can take on the role of warning, protection or destruction. When in a society, where societal anxiety prevails, a larger amount of individuals identifies with a caesaristic leader and projects their anger and aggressions into an imagined enemy who has been constructed by ideology and a conspiracy theory, then the danger of dictatorship or even fascist dictatorship according to Neumann becomes real.

Destructive collective anxiety can emerge when one or several of the following factors are present (Neumann 1957, 288-293; Neumann 2017, 624-628):

a) the alienation of labour,

b) destructive competition,

c) social alienation: a group fears or is threatened by the decline of "its prestige, income, or even its existence" and "does not understand the historical process or is prevented from understanding it” (Neumann 1957, 290; Neumann 2017, 624),

d) political alienation in respect to the political system,

e) the institutionalisation of anxiety (for example in the form of a totalitarian movement, propaganda or terror),

f) destructive psychological alienation and persecutory anxiety.

Neumann gives the following summary of these six dimensions:

"Neurotic, persecutory anxiety can lead to ego-surrender in the mass through affective identification with a leader. This caesaristic identification is always regressive, historically and psychologically. [...] An important clue for the regressive character is the notion of false concreteness, the conspiracy theory of history. [...] The intensification of anxiety into persecutory anxiety is successful when a group (class, religion, race) is threatened by loss of status, without understanding the process which leads to its degradation. [...] Generally, this leads to political alienation, i.e., the conscious rejection of the rules of the game of a political system. [...] The regressive mass movement, once it has come to power must, in order to maintain the leader-identification, institutionalize anxiety. The three methods are: terror, propaganda, and, for the followers of the leader, the crime committed in common." (Neumann 1957, 293-294; Neumann 2017, 628)

Neumann's analysis is so topical today because many of these factors are present in various parts of the world: Neoliberal capitalism has intensified the alienation of labour, destructive competition, large-scale fear of social decline, political apathy and a lack of trust in the political system, political parties, politicians and democracy, the institutionalisation of anxiety in the form of demagogic, nationalist, xenophobic farright movements, and the large-scale psychological desires for not just social change, but destructive social change. At the same time, we have seen a relative weakness and fractioning of the political Left and a shift of social democracy towards the right and neoliberalism that has been going on for decades. Contemporary societies may as a combination of these conditions be at a tipping point, where quantity turns into a new quality. Neumann argues that persecutory anxiety can take on three methods: "terror, propaganda, and, for the followers of the leader, the crime committed in common" (Neumann 1957, 294; Neumann 2017, 628). In many parts of the 
world, anxiety has taken on at least one of these elements, namely right-wing propaganda. In some, it has also already taken on others too.

Consider the following two examples of political communication on Twitter:

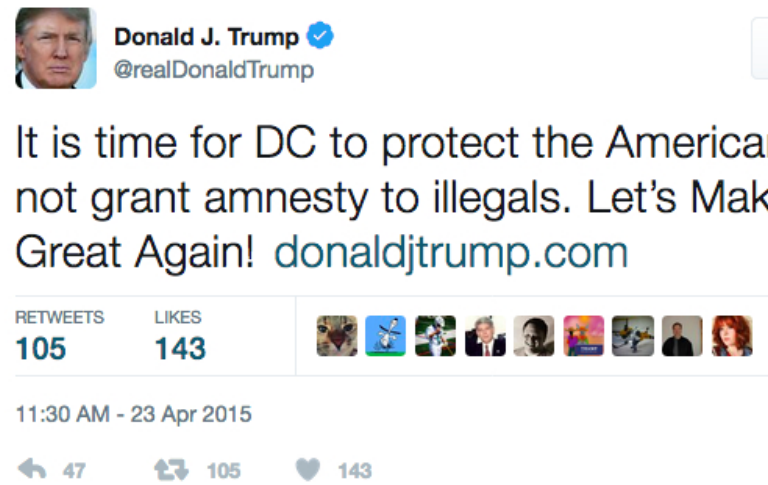

2+ Follow

Figure 1: Tweet by Donald Trump (Example 1)

Donald J. Trump

(1)realDonaldTrump

2+ Follow

We should be concerned about the American

worker \& invest here. Not grant amnesty to

illegals or waste \$7B in Africa.

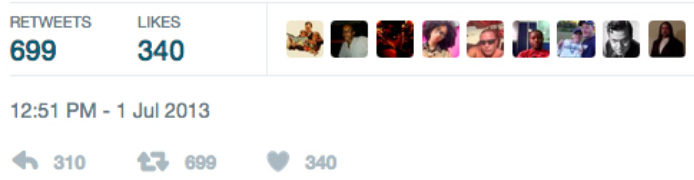

Figure 2: Tweet by Donald Trump (Example 2)

How can Anxiety and Politics help us to understand the political-economic, ideological and psychological dimensions of such social media postings? Trump appeals in his political communication to those, who feel or fear the negative impacts of capitalism, neoliberalism, inequalities, unemployment, social decline, or de-industrialisation. He speaks to those who feel or have the fear that their labour is or could become highly alienated (a) and that capitalism's new-imperialist globalisation has resulted in destructive competition that brings about precarity and unemployment (b), to those who feel or fear that their social status declines (c), and to those who are fed up with the existing political parties, politicians, and politicians whom they see as corrupt elites (d). Trump himself is as a political Leader an institutionalisation of such anxieties (e). He communicates simple nationalist solutions to complex problems by using right-wing ideology as destructive political response to anxiety (f).

Trump's nationalist ideology claims he will bring about change that means a return to a better past. It says it "make America great again". He says that the USA's national greatness is under attack by China, Mexico, illegal immigrants, Africans, the transfer of taxes to foreigners, and development aid. He identifies Americanness and the American interest with the American working class and un-Americanness with developing countries and immigrants.

Trump combines two semiotic chains: The chain of negative associations (amnesty, illegals, waste, Africa) is ideologically set into a relation to the chain of positive 
associations (protect, invest, concern, workers, America, greatness). The total message is that the USA is under attack and threatened by immigrants, the developing world, and everything foreign. Trump identifies US labour and US capital as having a joint national interest that is under external attack. He presents political-economic conflict as an antagonism between nations and thereby deflects attention from the class contradiction between capital and labour and power inequalities that are at the heart of contemporary crises. Trump communicates a state of exception and constant crisis that would require his political leadership in order to "make America great again". What is missing and what he tends not to mention is that US capital is transnational not just exploits US workers, but also migrant workers and workers in developing countries.

Right-wing authoritarianism responds to political-economic crises with ideologies that speak to disenfranchised individuals' psychology. Those who feel politically anxious have an ambiguous relationship to love and hate. They seek for an alternative and identity that promises them hope and they want to express their anger and aggression. Figures like Trump on Twitter and in other forms of public communication institutionalise anxiety by offering opportunities to these individuals for loving the nation and the Leader and expressing hatred against scapegoats. Right-wing authoritarianism works on the level of psychological anxieties, fires, desires, emotions, affects, and instincts. It often does not use rational arguments, but post-truth political psychology and ideology. A key question for progressive movements is how to respond to such movements. Rational arguments and statistics that deconstruct farright claims are often not enough. The question arises what political strategies are best suited for turning the love for the Leader and the nation into the love for humanity, democracy and socialism and the hatred against immigrants and refugees into the critique of capitalism.

\section{Axel Honneth on Anxiety and Politics}

Axel Honneth (2009, 146-156) focuses in his essay Anxiety and Politics: The Strengths and Weakness of Franz Neumann's Diagnosis of Social Pathology in some detail on the article by Neumann that tripleC republished. Honneth is interested in Neumann's essay because it deals with social pathologies of society, a key theme in Honneth's theory of recognition. Honneth $(2009,150)$ claims that Neumann "distinguishes emotional or affective types of identification from those free of affective components. [...] He is convinced that this second type of identification is exclusively rational and, hence, does not constitute an example of individual regression". The implication would be that there is "an affect-free identification" (Honneth 2009, 151).

It is on the one hand true that Neumann distinguishes between affective and nonaffective identification and considers the second one less regressive (Neumann 1957, 278; Neumann 2017, 618). But he sees non-affective identification as operating for example between lovers and small groups and says that there is a cooperative form of affective identification. These considerations seem somewhat paradoxical because lovers certainly always have an emotionally-driven relationship and Neumann characterises small group relations as both affective and non-affective. It seems therefore more likely that what he has in mind is a Freudian distinction between an identification that is based on dominance of the death drive and aggression on the one hand and one that is based on the life instincts on the other hand. The first has caesaristic and authoritarian potentials, the second co-operative potentials that can contradict authoritarianism. Both forms certainly involve emotions. 
Honneth $(2009,151)$ continues by saying that Neumann assumes that all forms of ego-boundary dissolution are reactionary and irrational. He here seems to misread Neumann, who says that the identification of the masses with leaders means "a nearly total ego-shrinkage" (Neumann 1957, 278; Neumann 2017, 618). Neumann is in his essay only concerned with the love to a leader that comes along with persecutory hatred against a constructed enemy. He does not analyse co-operative love that is free of hate and the role of the ego in it. He rather leaves open this question. A fascist group always demands total subsumption of the ego to the nationalist collective and its leader. Collectivism and the collective identification with the leader trump the individual. In a social relationship that is based on co-operation, love and eros without persecutory and annihilatory hatred against an ideologically constructed enemy, and the belief in a world of equal humans without the friend/enemy-logic, a dialectic of the individual and the group becomes possible (see Johanssen 2016).

Honneth argues that Neumann bases his analysis on a "Freudian orthodoxy" (Honneth 2009, 152) as represented by Adorno and Horkheimer at the Institute for Social Research (he forgets to add Marcuse). Honneth thinks that "psychoanalytic 'revisionism'" (Honneth 2009, 155) as represented by Erich Fromm is more appropriate. As a consequence, Honneth $(2009,154)$ criticises that Neumann's approach would be "tailored so much to the exceptional case of German National Socialism". Honneth misjudges the strengths of Neumann's approach: By pointing out the role of conspiracy theories, anti-Semitism, terror, genocide and annihilation, Neumann does not say that authoritarianism always and with necessity leads to Auschwitz, but that negative factories of mass annihilation are the negative potential of authoritarianism and can be its final consequence, which is why we better ought to be critical of it.

\section{Franz Neumann Today}

If Franz L. Neumann were alive today, he would stress that nationalism, xenophobia, and right-wing authoritarianism pose threats to democracy and the rule of law and that the key political task is to defend the civil liberties, political rights and social rights that constitute democracy. The very problem is that neoliberal capitalism has so much undermined social rights that civil and political rights have become endangered by a negative dialectic that has advanced destructive political forces. The only feasible alternative is a democratic front that defends social, political cultural rights against the threat of right-wing authoritarianism.

Neumann's article Anxiety and Politics reminds us that in such situation, the role of academics should be that they more than ever act as critical public intellectuals:

Hence there remains for us as citizens of the university and of the state the dual offensive on anxiety and for liberty: that of education and that of politics. Politics, again, should be a dual thing for us: the penetration of the subject matter of our academic discipline with the problems of politics-naturally, not dayto-day politics - and the taking of positions on political questions. If we are serious about the humanization of politics; if we wish to prevent a demagogue from using anxiety and apathy, then we-as teachers and students-must not be silent. We must suppress our arrogance, inertia, and our revulsion from the alleged dirt of day-to-day politics. We must speak and write. [...] Only through our own responsible educational and political activity can the words of idealism become history" (Neumann 1957, 294-295; Neumann 2017, 629). 


\section{References}

Erd, Rainer. 1985. Reform und Resignation: Gespräche über Franz L. Neumann. Frankfurt am Main: Suhrkamp.

Fuchs, Christian. 2017. Donald Trump: A Critical Theory-Perspective on Authoritarian Capitalism. tripleC: Communication, Capitalism \& Critique 15 (1): 1-72.

Fuchs, Christian. 2016. Reading Marx in the Information Age. A Media and Communication Studies Perspective on "Capital Volume l". New York: Routledge.

Gurland, Arkadij R. L. 1941. Technological Trends and Economic Structure under National Socialism. Zeitschrift für Sozialforschung 9 (2): 226-263.

Held, David. 1990. Introduction to Critical Theory: Horkheimer to Habermas. Cambridge: Polity.

Honneth, Axel. 2009. Pathologies of Reason: On the Legacy of Critical Theory. New York: Columbia University Press.

Horkheimer, Max. 1941. The End Of Reason. Studies in Philosophy and Social Science 9 (3): 366-388.

Horkheimer, Max. 1940. The Authoritarian State. In The Essential Frankfurt School Reader, ed. Andrew Arato and Eike Gebhardt, 95-117. New York: Continuum.

Jay, Martin. 1996. The Dialectical Imagination: A History of the Frankfurt School and the Institute of Social Research, 1923-1950. Berkeley, CA: University of California Press.

Johanssen, Jacob. 2016. The Subject in the Crowd: A Critical Discussion of Jodi Dean's "Crowds and Party". tripleC: Communication, Capitalism \& Critique 14 (2): 428-437.

Marcuse, Herbert. 1942. State and Individual Under National Socialism. In Collected Papers of Herbert Marcuse, Volume One: Technology, War and Fascism, ed. Douglas Kellner, 67-92. London: Routledge.

Marcuse, Herbert. 1941. Reason and Revolution: Hegel and the Rise of Social Theory. London: Routledge \& Keagan. Second edition.

Marcuse, Herbert. 1934. The Struggle against Liberalism in the Totalitarian View of the State. In Negations: Essays in Critical Theory, 3-42. London: Free Association.

Neumann, Franz. 2009/1944. Behemoth: The Structure and Practice of National Socialism, 1933-1944. Chicago, IL: Ivan R. Dee.

Neumann, Franz. 2017. Anxiety and Politics. tripleC: Communication, Capitalism \& Critique 15 (2): 612-636.

Neumann, Franz. 1957. The Democratic and the Authoritarian State: Essays in Political and Legal Theory, ed. Herbert Marcuse, Glencoe, IL: Free Press.

Neumann, Franz L. 1943. Anti-Semitism: Spearhead of Universal Terror. In Secret Reports on Nazi Germany: The Frankfurt School Contributes to the War Effort, ed. Raffaele Laudani, 27-30. Princeton, NJ: Princeton University Press.

Neumann, Franz L. 1936a. European Trade Unionism and Politics. New York: League for Industrial Democracy.

Neumann, Franz L. 1936b. The Governance of the Rule of Law. An Investigation into the Relationship Between the Political Theories, the Legal System; and the Social Background in the Competitive Society. Dissertation. London: London School of Economics.

Neumann, Franz L. 1923. Rechtsphilosophische Einleitung zu einer Abhandlung über das Verhältnis von Staat und Strafe. Dissertation. Frankfurt am Main: Johann Wolfgang Goethe-Universität.

Pollock, Friedrich. 1941a. Is National Socialism A New Order? Studies in Philosophy and Social Science 9 (3): 440-455.

Pollock, Friedrich. 1941b. State Capitalism. Studies in Philosophy and Social Science 9 (2): 200-225.

Scheuerman, William E. 1997. Between the Norm and the Exception: The Frankfurt School and the Rule of Law. Cambridge, MA: MIT Press. 
Söllner, Alfons. 2001. Franz Neumann's Place in the History of Political Thought: A Sketch, In: German Scholars in Exile. New Studies in Intellectual History, eds. Axel Fair-Schulz and Mario Kessler, 121-135. Lanham, MD: Rowman \& Littlefield. 2011.

Söllner, Alfons. 1996. Deutsche Politikwissenschaftler in der Emigration. Studien zu ihrer Akkulturation und Wirkungsgeschichte. Mit einer Bibliographie. Opladen: Westdeutscher Verlag.

Söllner, Alfons. 1982. Neumann zur Einführung. Hannover: Soak.

Wiggershaus, Rolf. 1995. The Frankfurt School: Its History, Theories, and Political Significance. Cambridge, MA: MIT Press.

\section{About the Author}

Christian Fuchs is co-editor of tripleC: Communication, Capitalism \& Critique

(http://www.triple-c.at). He is a professor at the University of Westminster. His research focuses on critical theory, media \& society, the Internet \& society. 